\title{
The Need To Train Specialists With Knowledge Of The Japanese Language In The Context Of The Modern Development Of Uzbek-Japanese Relations
}

Rasuleva Ilmira Djurayevna

Teacher At University Of World Economy And Diplomacy, Tashkent, Republic Of Uzbekistan

\section{ABSTRACT}

This article analyses the economic and political aspects of relations between the Republic of Uzbekistan and Japan. The importance of bilateral relations between the Republic of Uzbekistan and Japan in terms of training highly qualified specialists is emphasized. The author points out that the importance of training specialists with knowledge of the Japanese language is important due to the following factors: the growth of economic cooperation between Japan and Uzbekistan, which indicates the need for training for negotiations and joint activities; development of cooperation in the field of joint research and participation in training; development of cooperation in the field of tourism.

\section{KEYWORDS}

Economics, linguistics, international relations, globalization, Japanese-Uzbek relations.

\section{INTRODUCTION}

Today, the Republic of Uzbekistan pursues a interstate relations on the basis of reciprocity. multi-vector policy for the development of In accordance with the Strategy of Action on 
the five priority areas of development of the Republic of Uzbekistan in 2017-2021, ensuring security, interethnic harmony and religious tolerance, implementing a balanced, mutually beneficial and constructive foreign policy aimed at strengthening the independence and sovereignty of the state, creating a belt of security, stability and good - neighbourliness around Uzbekistan, strengthening the international image of the country, are one of the priority areas of the state's development ${ }^{1}$.

The history of Uzbek-Japanese relations goes back centuries. Trade, economic, cultural and humanitarian ties were developed during the Great Silk Road. According to the Japanese artist, honorary citizen of the city of Tashkent Ikuo Hirayama, it was the Great Silk Road that was the only opportunity for isolated Japan to join the world culture and feel part of the universal civilization ${ }^{2}$.

The need to train specialists with knowledge of the Japanese language is expressed in the following:

\section{The growth of economic cooperation between Japan and Uzbekistan, which indicates the need for training for negotiations and joint activities.}

The Republic of Uzbekistan has established mutually beneficial relations with Japan, continuing in the first years of independence. Despite the serious changes in interstate relations due to the coronavirus pandemic, the relations between Uzbekistan and Japan are strengthening the multifaceted

${ }^{1}$ Strategy of Action on the five priority areas of development of the Republic of Uzbekistan in 20172021 (https://strategy.uz/files/news/45467/eng.pdf).

${ }^{2}$ https://yuz.uz/ru/news/uzbekistan-i-yaponiya-novyvitok-v-razvitii-dvustoronnix-otnosheniy cooperation that meets the strategic interests of the two countries.

Active political dialogue at the highest level contributes to the deepening of mutually beneficial economic relations between the two countries. In turn, the positive dynamics of trade and economic relations between the two countries is the basis for further development of cooperation between Uzbekistan and Japan.

Despite the negative impact of the pandemic on the world economy, Japan is actively investing in the territory of the Republic of Uzbekistan. In April 2020 alone, Japan's foreign direct investment in the world increased by 14.5 billion dollars, compared to 132 billion dollars in March. In terms of GDP, Japan ranks third in the world (4.9 trillion dollars), and in terms of trade - fourth, with annual imports exceeding 700 billion dollars.

On the territory of Uzbekistan, there are several dozen enterprises with the participation of Japanese investments. Representatives of 15 Japanese companies are accredited. Leading Japanese companies such as JOGMEC, Mitsubishi, Itochu, Sumitomo, Marubeni, Isuzu and others operate in Uzbekistan. The functioning of the UzbekJapanese Committee for Economic Cooperation makes a significant contribution to the development of bilateral trade ${ }^{3}$.

Japanese entrepreneurs highly appreciate the reforms and transformations carried out in Uzbekistan, and emphasize that the liberalization of the currency and tax systems,

https://isrs.uz/ru/maqolalar/uzbekistan-i-aponiasotrudnicestvo-osnovannoe-na-vzaimovygodnyhinteresah 
the simplification of visa procedures have created additional opportunities for successful business in Uzbekistan. The partners point out that the first official visit of the President of Uzbekistan Shavkat Mirziyoyev to Japan gave a new dynamic to mutually beneficial relations between the business circles of the two countries and became an incentive for more active participation of Japanese business, including small and medium-sized businesses, in the implementation of investment projects in the country.

This is also evidenced by a solid package of agreements concluded in 2019 with Japanese business circles in the amount of 6.5 billion dollars for the implementation of a number of joint projects in the field of energy, modernization of industry and agriculture, infrastructure, ecology, health and other sectors.

In the future, according to experts, in the context of the desire of the leadership of Uzbekistan to improve the investment climate, the formation of sustainable business rules in the country and the prevention of transport isolation through the implementation of transport and communication projects, the interest of Japanese business circles in the Uzbek market will grow.

\section{Development of cooperation in the field of joint research and participation in training.}

Japan's strong industrial potential, based on the most advanced scientific and technological solutions, makes the country of the Rising Sun an important partner that can play a positive role in the economic development

and

technological modernization of Uzbekistan.

Moreover, cooperation mechanisms have already been established in this direction, and the parties have a positive experience of interaction. In particular, in cooperation with the Japanese international cooperation Agency JICA, the Uzbek-Japanese Youth Innovation Centre was established at the Tashkent State Technological University. The Centre specializes in research in such areas as chemistry and petro chemistry, mining and deep processing of mineral resources, energy, renewable energy sources and energy conservation, mechanical engineering and materials science.

It is necessary to emphasize the importance of signing agreements between Uzbekistan and Japan on the creation of a High-tech Park in Tashkent. These structures will become a solid platform for ensuring the technological development of key areas of our country's economy, laying the foundation for the training of young, promising personnel.

Another achievement of bilateral cooperation in the field of science and technology was the approval of the project presented with the assistance of the Ministry of Innovative Development of the Republic of Uzbekistan and Professor Kristina Toderich (Tottori University, Japan) in the prestigious SATREPS2020 competition in Japan. In June 2020, this project was recognized as the best among 10 international projects selected by the Japan Agency for Science and Technology.

The project "Development of new technologies for monitoring and controlling the use of water resources to combat 
salinization and improve land productivity and food security in the Aral region" was presented by the International Innovation Center of the Aral Sea Region under the President of the Republic of Uzbekistan together with leading scientists from 8 universities in Japan.

Japan views Uzbekistan as a key state in the Central Asian region in terms of geographical location and economic potential. This is evidenced by the fact that about $57 \%$ of the total amount of Japanese aid allocated to the region falls on Uzbekistan.

In total, from 1993 to 2019, JICA provided: concessional loans totaling 2.52 billion dollars. Also, 329 students became applicants for Japanese government grants for master's and doctoral studies at Japanese universities, and 2,416 Uzbek specialists completed internships in Japan. 335 volunteers were sent to Uzbekistan in the fields of Japanese language, computer technology, business management, economics, law, healthcare, sports, and tourism.

The Japan Bank for International Cooperation (JBIC) has implemented seven projects totaling 1.9 billion dollars, provided commercial loans for 721 million dollars, including the construction of the Shurtan gas chemical Complex (622.2 million dollars), the Bukhara Oil Refinery (59 million dollars), the compressor station at the Kokdumalak field (76 million dollars), and the reconstruction of the Ferghana refinery ( 83 million dollars).

\section{Development of cooperation in the field of tourism.}

It is also possible to emphasize the dynamic development of the tourism industry within the framework of the Memorandum of Cooperation in the field of tourism concluded during the visit between the State Committee of the Republic of Uzbekistan for Tourism Development and the Japan Tourism Agency for 2020-2022.

The decision of the Japanese company H.I.S. Holdings to build Japanese-style hotels in Tashkent and Samarkand and open its office to attract tourists from Japan demonstrates the great interest of the Japanese population in the tourist heritage of our country.

According to experts, to restore the tourism sector in the context of a pandemic, domestic entrepreneurs can introduce modern Japanese technologies, methods to ensure sanitary and epidemic standards and safe tourism. For example, in July this year, the Japanese company Global Agents announced that it will introduce a system of contactless guest service in all its hotels. In addition to the use of new technologies in cleaning rooms, the company began to serve guests without contact using new applications and observing a social distance between the staff and guests of the hotel.

Today, Uzbek is taught in a number of leading Japanese universities. Six universities in Uzbekistan train personnel with knowledge of Japanese. Therefore, for the Republic of Uzbekistan, the training of specialists in Japanese studies-philologists, literary critics, philosophers, historians, political scientists, and economists is of great importance.

For three decades, Japanese teachers have been creating an educational, methodological, and scientific basis for the development of the study of the Japanese language in our 
republic. Along with domestic specialists, Japanese teachers and scientists, who still carry out labour and scientific activities in the university, made a great contribution to the development of this direction in Uzbekistan.

It should be noted that the University of World Economy and Diplomacy operates the only Japanese research and Analytical centre in the Central Asian region.

The main goal of the Centre is to deepen Uzbek-Japanese relations in all spheres, to ensure the implementation of the Presidential Decree of October 8, 2019 "On approval of the Concept for the Development of Higher Education in the Republic of Uzbekistan until 2030".

The strategic partnership established between the two countries in 2002 is developing dynamically in the fields of science, education and innovation, along with political, interparliamentary, trade and economic, investment, cultural and humanitarian, innovation and tourism.

In particular, the Japanese Law Centre created by Nagoya University at the Tashkent State University of Law, the Uzbek-Japanese Youth Innovation Centre at the Tashkent State Technical University, the Japanese Media Training Centre at the Tashkent University of Information Technologies, the Faculty of Japanese Studies at the Tashkent State Institute of Oriental Studies. The mechanism of the conference of rectors of Uzbekistan and Japan is a clear proof of this.

After the independence of our country, more than five thousand Uzbek young people were trained at various universities in Japan and comprehensively use all their knowledge and experience for the prosperity of our Motherland.

The UMED scientific and educational process is also aimed at actively participating in the rapprochement of the two countries. It has successfully implemented student exchange programs with prestigious universities in Japan for many years, as well as well-known Japanese specialists constantly conduct classes not only on the Japanese language, but also on the modern economy, domestic and foreign policy of Japan.

In our opinion, the training of specialists with knowledge of the Japanese language will allow for fundamental research of important political, economic, social and cultural processes taking place in this country, Japan's international initiatives, international relations, foreign policy concepts and practical efforts, problems and solutions.

The training of specialists will significantly increase the academic potential and capabilities of Uzbekistan's universities, the quality of youth education, and the bilateral relations between Japan and Uzbekistan.

\section{REFERENCES}

1. Strategy of Action on the five priority areas of development of the Republic of Uzbekistan in 2017-2021 (https://strategy.uz/files/news/45467/eng. pdf).

2. https://yuz.uz/ru/news/uzbekistan-iyaponiya-novy-vitok-v-razvitiidvustoronnix-otnosheniy 
The American Journal of Social Science and Education Innovations (ISSN - 2689-100x)

Published: May 31, 2021 | Pages: 446-450

Doi : https://doi.org/10.37547/tajssei/Volume03Issue05-79

2021: 5.857

OCLC - 1121105668

3. https://isrs.uz/ru/maqolalar/uzbekistan-iaponia-sotrudnicestvo-osnovannoe-navzaimovygodnyh-interesah 